\title{
Reducing barriers and inequality by hosting conferences in developing countries.
}

\author{
Brett Buttliere
}

Scientific conferences are big business, and there are many advantages to intentionally selecting smaller and less developed nations as venues for our conferences; beyond the simple cost savings and the extra value one gets for the money. The keys are really that a better experience can be provided, for everyone, for less money, which lowers the barriers to entry especially for students who pay their own way and local scientists who otherwise suffer from exchange rate penalties. This is not only good for the scientists(' funders), but also for the local communities by encouraging science, openness, and high quality foreign experience. And in general the places are simply better to go to, afterall, who needs to go to London for the $5^{\text {th }}$ time?

When conferences are held e.g., in cities like New York, London, or Shanghai, these are among the most expensive places in the world and the collective spends extra money for less value. Hotels cost more, food costs more, and same money can buy double or even triple in other locals, while also helping those local economies grow, rather than reinforce existing inequalities and contributing to the so called Matthew or rich get richer effects. Rather than endorsing and promoting this system of inequality, we can encourage and promote diversity and inclusion by hosting conferences in lesser known places, and especially developing countries, that can also often benefit more from the money, as well

\section{Expensive conference locations are exclusionary of developing world scientists}

Conferences in expensive locations not only cost more for the societies involved, relative to the value being received, they are actually exclusionary of scientists that are from developing nations. When one works and lives in a developing nation, where the currency is not valued equally, going to 'higher status' nations is extra costly, simply because of the exchange rate, never mind going to the most expensive places in the world. A night in a London Hotel

The high costs of conferences.

Imagine a small conference of 70 people for two days (e.g., a Thursday and Friday), in your field. How much does that conference cost the collective that pays for that conference to happen, in total? Ten thousand? Fifty thousand? One hundred thousand? It is often far more.

Just for the venue, things like the food, drinks, tables and chairs, cleaning, parking passes, and etc, the University of Maryland estimates the cost for 70 people, two days, to be $\sim \$ 20,000$ (University of Maryland). This is what the University charges to use their facilities, and so hopefully has less profit built into it than at e.g., a hotel or conference venue. Hotel costs for the visiting scholars is another $\$ 20,000$, assuming a hotel room is $\$ 100$ per night (haha) and people stay two or three nights (e.g., the night before the conference, or the night after). Even if it is a regional or national conference, the costs are likely again to be another $\$ 100$ each way, on average, and that is another $\$ 14,000$. The scientists themselves are paid between $\$ 100$ and $\$ 200$ dollars a day to travel and be there, and that is another $\$ 20-30,000$. These numbers are conservative in the extreme, but already near $\$ 100,000$, just for

this small conference, without considering even opportunity costs.

One hundred dollars does not get a hotel room in London, they are 200 on average, while in Maribor, or Rabat Morocco, it can get an entire apartment, not just a hotel room. By moving conference locations to less well developed places the money brings not only more, but it also helps the local economy relatively more, and lowers barriers to entry for developing nations. costs a european researcher about a day's work ( 100-300 euros), but for a researcher from a developing nation it can be two three or even a week's work. This of course is prohibitively expensive, and even when the university pays for the hotel, with a meal allowance, every little thing is costing the developing researcher a half a day compared to the first world researcher's hour. The common comparison is the Big Mac Index, where it takes the average Swiss McDonald's employee 10.6 minutes of their time to buy a Big Mac, while it takes an Egyptian 62.5 minutes to buy the same (Ashenfelter, \& Jurajda, 2001, Big Mac Index, 2018).

These high costs limit the number of people that can go and endorse existing inequalities in the systems of the world. Especially in the situation of students who often pay their own way, hosting conferences in expensive locations serves as a barrier for developing world scientists. While it costs everybody more to go to those locations, those whose time is already valued less (though exchange rates) pay a double tax. Conversely, if a conference is held in a developing nation, it is less expensive 
not only for local scientists and students, but doubly so for those who come from rich nations.

\section{Developing countries also offer better bang for the scientist's buck.}

These effects of the currency differential that make expensive locations exclusionary for developing world researchers are exactly reversed when researchers go from richer countries to less rich ones. Their money is extended two, three, or even four fold, even without leaving Europe, for instance. Going from London or Paris, which are some of the richest cities in the EU, to Nürnberg, Prague, Bratslavia, Bologna, Zagreb, or Budapest brings better value for the same money and indeed even more adventure, as they are places you have not been already three or four times.

A personal example here will help, I had a travel budget of 1000 euros and decided to try and split it into two conferences, paying the rest from my own pay, as many students do. I chose to go to London for a scholarly communication conference, and to Marmaris, Turkey, for a 'developing world' conference on technology in science and science education (much of my work is on how digital infrastructure can benefit science communication). Both trips involved an approximately 2 hour 100 euro flight, but in order to make the budget for the London Trip I slept in a room with 6 other people snoring all night, while in Marmaris I had my own large room, with a balcony, at a resort with three pools and buffet with the foods you want any time. The London Conference Venue did provide sandwiches for lunch, coffee, and drinks, but it is not comparable with a 'free', open all the time, buffet that is 100 meters from the beach! The conference fee, including the stay at the resort, was 350 euros, and you could talk to the employees and hear how it was improving their lives (and mine!). There was plenty of space, and the weather was fantastic, though maybe a bit cold for swimming in the Mediterranean.

This experience was a turning point for me. It is absolutely true the conference did not have the most cutting edge work at it, and that the projects were smaller than might be seen in an 'elite' conference in London. But there was equal excitement and pride in the projects, and these researchers were eager to hear more and receive feedback and assistance if I had it. More than that, it was luxury, truly, and less than I was sleeping in a dirty apartment in London for.

Travel has been one of the major perks of academia for a long time, but does one really need to go to London or Chicago or New York for the $5^{\text {th }}$ or $10^{\text {th }}$ time? It might make it easier in some sense, but why not travel to Ljubliana or Maribor, Slovenia, or Prague, Budapest, Zagreb, Sarajevo, Bari, they may not be the first places you think of, but indeed spreading the love a little bit can be good for everyone. Especially when the topic of the conference can be related to development, it makes sense to host it where it can be of most benefit. A meeting on solar energy in e.g., Morocco.

\section{Saving the world one adventure at a time}

There are also benefits beyond those directly involved in the conference, benefits to the wider community both in the developing and developed nations. The money that the conference injects into the local economy is significant, especially in developing nations, and can be a significant force for good. The word of mouth alone is significant, assuming the people have a good time, between scientists telling their international friends about neat places they've been to and locals telling each other about the interesting scientists in town for the week. Bringing science to the developing world in a friendly, useful, way is worth it alone.

Conferences can also afford the local community lasting benefits beyond the immediate scope of the conference. Especially when the conference can coincide with (the creation of?) a department in the area, it brings a sustainable good that will last even farther than that influx of money. Some of the saved conference expenses can be used to provide a durable good for the community, such as a hydroelectric or solar plant. Even the extra flight money being spent to getting to these is doing a good in the world as it is establishes the air lines, airports, and infrastructure, also for local people. Some time ago, conferences could be considered a subsidy for the development of airports for the general 
public, but in the last 10 years it has been economized enough that air travel is open to the developed world. Thus, it is time to take the academic travel subsidy toward the developing nation, to economize travel there as well.

There could be some safety concerns, but the point is not to take conferences into war zones, or to push local infrastructure beyond its means, simply to be a bit more intentional about where conferences are held. The idea is just that if the conference organizing committee has someone from London and someone from Zagreb, that maybe the conference can be done in Zagreb; of course without being an extra burden on that committee member. My own idealistic hope is that these communities sees the value that these conferences are doing and puts in the work to solve the minor problems that might come up (e.g., more intercity infrastructure, cracking down on pick pocketing), which also provides durable goods to the community.

\section{The final statement}

The academic community can promote equality and reduce exclusionary forces by intentionally choosing to host conferences in less well developed and expensive venues. This has the double benefit that those from developing nations do not suffer (as much) from the currency exchange rates, and it actually makes that 'currency tax' into a 'currency benefit', such that the money's power is multiplied, providing more for the same money. This simple practice lowers the economic barrier especially for students and scientists in developing nations, it injects stimuli into those developing economies, and it provides high quality foreign experience for everyone, reducing xenophobia and increasing the love of science in especially those places where it is needed most. A proposal that is better for everybody involved should be easily implemented. 


\section{Works Cited}

Ashenfelter, O., \& Jurajda, S. (2001). Cross-country comparisons of wage rates: The Big Mac index. Unpublished paper, available at http://economics. uchicago. edu/download/bigmac. pdf.

Big Mac Index (2019). Accessed on Dec. 30, 2019, at: https://en.wikipedia.org/wiki/Big_Mac_Index

Kirchherr, J., \& Biswas, A. (2017). Expensive academic conferences give us old ideas and no new faces. The Guardian, 30.

University of Maryland, 2019. Conference Budget Estmates. Accessed on Dec. 30, 2019, from: https://www.rhsmith.umd.edu/files/Documents/Offices/OSPE/ConferenceBudgetEstimates.pdf

Society for Personality and Social Psychology, 2019. Hotel Options \& Rates. Accessed on Dec. 30, 2019, from:

http://meeting.spsp.org/travel-lodging/hotel-options-rates 